\title{
HUBUNGAN PERSEPSI PETANI TERHADAP PERAN PENYULUH PERTANIAN LAPANGAN (PPL) DENGAN TINGKAT ADOPSI INOVASI RICE TRANSPLANTER DI KECAMATAN KEBAKKRAMAT KABUPATEN KARANGANYAR
}

\section{PERCEPTION OF FARMERS RELATIONSHIP WITH THE ROLE OF AGRICULTURAL EXTENSION WORKERS WITH THE LEVEL OF ADOPTION OF RICE TRANSPLANTER INNOVATION IN SUB DISTRICT KEBAKKRAMAT DISTRICT KARANGANYAR}

\author{
Riska Aprilia, Eny Lestari, Bekti Wahyu Utami \\ Program Studi Penyuluhan dan Komunikasi Pertanian Fakultas Pertanian \\ Universitas Sebelas Maret Surakarta \\ Jl. Ir. Sutami No. 36 A Kentingan Surakarta 57126 Telp./ \\ Fax (0271) 637457 \\ Email: riskaa@student.uns.ac.id/ Telp.089604330883
}

\begin{abstract}
This study aims to examine the role of extension workers in Kecamatan Kebakkramat. furthermore, this research is to examine the level of adoption of technological innovation of rice transplanter and to analyze the relationship between farmers perceptions on the role of Agricultural Field Extension (PPL) with the level of adoption of rice transplanter innovation in Kecamatan Kebakkramat. The basic method of this research is quantitative descriptive method with survey technique. The location of this research is determined by purposive that is in District Kebakkramat Karanganyar Regency. Sampling was done by quota sampling with 60 respondents spread in three villages, Waru Village, Pulosari Village, and Nangsri Village, this is done because in these three villages have applied rice transplanter. The data analysis of this research using wide interval formula and rank spearman correlation analysis method ( $\mathrm{rs}$ ). The results shows that the perception of farmers on the role of extension workers as Educator (X1), Motivator (X2), Disseminator (X3), Supervisor (X4), and Facilitator (X5) in medium category or can be good. There is a significant correlation between the role of extension agent as Motivator (X2) with the adoption rate of rice transplanter innovation is at $95 \%$ confidence level and the most significant correlation between extension agent role as Disseminator is at $99 \%$ (X3) level of trust. As for the role of Education (X1), Supervisor (X4), and Facilitator (X5) have no significant relationship with the adoption rate of rice transplanter innovation.
\end{abstract}

Keywords: Adoption of Innovation; Extension of Role; Farmers Perception; Rice Transplanter.

Abstrak: Peneltian ini bertujuan untuk mengkaji peran penyuluh di Kecamatan Kebakkramat, mengkaji tingkat adopsi inovasi inovasi teknologi rice transplanter, dan menganalisis hubungan antara persepsi petani terhadap peran Penyuluh Pertanian Lapangan (PPL) dengan tingkat adopsi inovasi rice transplanter di Kecamatan Kebakkramat. Metode dasar penelitian ini adalah metode deskriptif kuantitatif dengan teknik survei. Lokasi penelitian ditentukan secara purposive yaitu di Kecamatan 


\title{
Aprilia, Lestari, Utami, Adopsi Inovasi; Peran Penyuluh,,,
}

\begin{abstract}
Kebakkramat Kabupaten Karanganyar. Pengambilan sampel dilakukan dengan quota sampling dengan jumlah 60 responden yang tersebar di tiga desa yaitu Desa Waru, Desa Pulosari, dan Desa Nangsri, hal ini dilakukan karena di tiga desa ini sudah menerapkan rice transplanter. Analisis data menggunakan rumus lebar interval dan metode analisis korelasi rank spearman $\left(r_{s}\right)$. Hasil penelitian menunjukkan bahwa persepsi petani terhadap peran penyuluh sebagai Edukator (X1), Motivator (X2), Diseminator (X3), Supervisor (X4), dan Fasilitator (X5) dalam kategori sedang atau dapat dikatan baik. Terdapat hubungan yang signifikan antara peran penyuluh sebagai Motivator (X2) dengan tingkat adopsi inovasi rice transplanter pada taraf kepercayaan sebesar $95 \%$ dan terpadat hubungan yang sangat signifikan antara peran penyuluh sebagai Diseminator pada taraf kepercayaan sebesar 99\% (X3). Sedangkan untuk peran penyuluh sebagai Edukator (X1), Supervisor (X4), dan Fasilitator (X5) tidak memiliki hubungan yang signifikan dengan tingkat adopsi inovasi rice transplanter.
\end{abstract}

Kata kunci : Adopsi Inovasi; Peran Penyuluh; Persepsi Petani;Rice Transplanter.

\section{PENDAHULUAN}

Pembangunan pada negara yang sedang berkembang umumnya dititik-beratkan pada sektor pertanian guna memperbaiki mutu makanan penduduknya dan untuk memenuhi kebutuhan pangan secara nasional (Suhardiyono, 1992). Pertanian sebagai titik sentral dalam pembangunan untuk meningkatkan kesejahteremiaan masyarakat, tidak akan tercapai jika petanianya tidak ada keingin maju. Usaha pembangunan pertanian harus dilakukan dengan pendekatan pembangunan berkelanjutan dengan peningkatan produksi pertanian yang harus didasari oleh adanya usaha mempengaruhi petani (Mardikanto dan Sutarni, 1982). Penyuluhan pertanian berperan penting bagi pembangunan pertanian, sebab penyuluhan merupakan salah satu upaya pemberdayaan petani dan pelaku usaha pertanian lain untuk meningkatkan produktivitas, pendapatan dan kesejahteraannya (Sairi, 2015).

Pembangunan pertanian tidak dapat hanya didukung oleh penyuluhan saja, tetapi juga dengan teknologi baru. Penerapan teknologi baru di bidang pertanian bertujuan untuk memudahkan kegiatan serta meningkatkan hasil pertanian sehingga perlu lebih banyak dilakukan sosialisasi dan pemahaman kepada masyarakat khususnya petani. Kebakkramat menurut BPS (2016) merupakan kecamatan dengan lahan persawahan terluas di Kabupaten Karanganyar, yaitu dengan luas wilayah tanah sawah $2.008 \mathrm{Ha}$ menjadikan kecamatan ini menjadi fokus dalam peningkatan hasil pertanian. Luas wilayah tanah sawah dirasa tidak seimbang dengan ketersediaan tenaga kerja pertaniannya, seperti yang dituturkan oleh Kepala BP3K Kebakkramat bahwa diwilayah 


\section{Jurnal Agritexts Volume 42 Nomer 2 Oktober 2018}

kebakkramat ini mengalami kekurangan tenaga tanam.

Kondisi tersebut tentunya dapat mempengaruhi produksi hasil pertanian, sehingga diperkenalkanlah mesin Rice Transplanter di Kecamatan Kebakkramat ini. Rice transplanter adalah jenis mesin penanam padi yang dipergunakan untuk menanam bibit padi yang telah disemaikan pada areal khusus dengan umur tertentu, pada areal tanah sawah kondisi siap tanam, mesin ini dapat mengurang tenaga tanam dari yang biasanya dibutuhkan. Pengenalan bagi suatu inovasi ini dirasa perlu untuk dikaji, khususnya pada hubungan persepsi petani terhadap peran Penyuluh Pertanian Lapangan (PPL) dengan adopsi inovasi rice transplanter. Adesina dan Zinnah (1993) menyebutkan bahwa "Technology adoption is a complex and a dynamic process that is determined by many factors such as perceived characteristics of the technologies, farmer circumstances and conditions. The adopter perception model suggests that the perceived attributes of innovations condition adoption behaviour". Adopsi teknologi adalah proses yang kompleks dan dinamis yang ditentukan oleh banyak faktor seperti karakteristik teknologi, keadaan dan kondisi petani. Model persepsi adopter menunjukkan atribut yang dirasakan dari inovasi menerapkan perilaku adopsi.

Peran penyuluh disini berpengaruh terhadap proses adopsi yang melalu persepsi petani terlebih dahulu. Tingkat persepsi petani merupakan pandangan petani terhadap peran penyuluh. Sedangkan adopsi merupakan tingkat penyerapan metode baru pada usahatani padi. Kedua hal ini diduga berhubungan. Adopsi petani diduga dipengaruhi oleh tingkat persepsi petani. Seperti diketahui sebelumnya bahwa penyuluh merupakan sumber pertama bagi petani dalam penyebaran suatu inovasi, sehingga peran penyuluh dirasa sangat mempengaruhi persepsi petani dalam mengambil keputusan untuk mengadopsi suatu inovasi yaitu mesin Rice Transplanter.

Penelitian ini akan membahas bagaimana persepsi petani terhadap peran PPL di Kecamatan Kebakkramati, bagaimana tingkat adopsi inovasi teknologi Rice Transplanter di Kecamatan Kebakkramat, dan bagaimana hubungan antaran persepsi petani terhadap peran Penyluh Pertanian Lapangan (PPL) dengan tingkat adopsi inovasi teknologi Rice Transplanter di Kecamatan Kebakkramat.

\section{METODE PENELITIAN}

Penelitian ini menggunakan pendekatan kuantitatif yaitu peneli- 


\section{Aprilia, Lestari, Utami, Adopsi Inovasi; Peran Penyuluh,נ,}

tian yang memusatkan pada pengumpulan data kuantitatif yang berupa angka-angka. Metode yang digunakan dalam penelitian ini yaitu metode deskriptif, dimana menggambarkan obyek yang diteliti melalui data sampel atau populasi sebagaimana adanya atau sesuai apa yang terjadi (Sugiyono, 2015). Penelitian ini menggunakan teknik survei, dimana teknik survei menurut Singarimbun dan Effendi (1986) merupakan penelitian yang informasinya dikumpulkan dari responden dengan menggunakan kuisioner sebagai alat pengumpul data.

Pemilihan lokasi penelitian dilakukan secara purposive di Kecamatan Kebakkramat dan desa di tentukan secara purposive yaitu dengan cara memilih desa-desa yang sudah memiliki alat tanam pindah padi atau yang disebut Rice Transplanter. Populasi dari penelitian ini adalah para petani komoditas padi di Kecamatan Kebakkramat. Penentuan sample dalam penelitian ini menggunakan teknik sampling Nonprobability sampling dengan metode Sampling Kuota yaitu menentukan sampel dari populasi yang mempunyai ciri-ciri tertentu sampai jumlah (kuota) yang diinginkan (Sugiyono, 2015). Jumlah sampel petani responden pada penelitian ini adalah 60 orang petani di Kecamatan Kebakkramat dengan pembagian 20 responden dari Desa
Nangsri, 20 responden dari Desa Pulosari, dan 20 responden dari Desa waru. Pengambilan responden atau pemilihan individu sebagai sampel dari setiap kuota dilakukan secara simple random sampling. Hal ini didasari atas kriteria responden yang sudah mengikuti penyuluhan atau pelatihan tentang penggunaan mesin Rice Transplanter.

Sumber data dalam penelitian ini yaitu data primer dengan melakukan wawancara menggunakan alat bantu berupa kuisioner serta melakukan observasi dan data sekunder yang didapat dari instansi terkait. Metode analisis data dalam pengukuran persepsi petani dan tingkat adopsi petani menggunakan kelas kategori (lebar interval). Selanjutnya menggunakan korelasi rank spearman $\left(r_{s}\right)$ untuk menguji adanya hubungan antara persepsi petani terhadap peran Penyuluh Pertanian Lapangan (PPL) dengan tingkat adopsi inovasi rice transplanter.

\section{HASIL PENELITIAN DAN PEMBAHASAN}

Kecamatan Kebakkramat merupakan salah satu kecamatan di Kabupaten Karanganyar dimana jarak dengan Kota Kabupaten hanya 15 KM. Luas wilayah Kecamatan Kebakkramat yaitu 3.645,63 Ha, yang terdiri atas $2.174,00 \mathrm{Ha}$ tanah sawah dan 1.471,63 Ha tanah kering (BPS, 2016). Jumlah penduduk tahun 2016 


\section{Jurnal Agritexts Volume 42 Nomer 2 Oktober 2018}

yaitu terdiri dari 35.462 laki-laki dan 36.853 perempuan. Penduduk ratarata berada pada usia produktif, namun ABT dalam angka 145 yang berarti 100 orang usia produktif menanggung 145 orang usia nonproduktif (BPS, 2016).

Kondisi pertanian dengan luas lahan tertinggi pada area persawahan menjadikan Kebakkramat menjadi sentra produksi padi di Karanganyar. Namun sayangnya tidak diimbangi dengan tenaga tanam yang memadai. Rice transplanter diperkenalkan di Kebakkramat pada bulan April 2016. Pengenalan inovasi tersebut dilakukan dengan acara serangkaian dari pemaparan materi hingga ke praktek. Rice Transplanter merupakan bantuan dari pemerintah dimana disalurkan melalui BPP Karanganyar dan selanjutnya diberikan kepada Desa yang selanjutnya pada aplikasi mesin tersebut dipantau oleh PPL, Desa yang sudah memiliki mesin rice transplanter yaitu Desa Nangsri, Desa Pulosari, dan Desa Waru.

\section{Persepsi Petani terhadap Peran Penyuluh Pertanian Lapang (PPL) terhadap Adopsi Inovasi Teknologi Rice Transplanter}

Persepsi petani akan tercermin dari adopsinya terhadap teknologi yang diperkenalkan kepadanya. To facilitate adoption, Extension educators should include information about the economic factors associated with an innovation's use. Profits are a major reason to adopt an innovation. Farmers assess an innovation based on economic facts and concepts, such as risk, past and present practices, production alternatives, and competing production practices. Extension educators must address economic factors and concepts to enhance a farmer's ability to make an informed decision (Robert and Timothy, 1995). Untuk memfasilitasi adopsi, pendidik ekstensi harus menyertakan informasi tentang faktor ekonomi yang terkait dengan penggunaan inovasi. Keuntungan adalah alasan utama untuk mengadopsi sebuah inovasi. Petani menilai sebuah inovasi berdasarkan fakta dan konsep ekonomi, seperti risiko, praktik masa lalu dan sekarang, alternatif produksi, dan praktik produksi bersaing. Pendidik ekstensi harus memperhatikan faktor dan konsep ekonomi untuk meningkatkan kemampuan petani dalam membuat keputusan Dalam proses ini penyuluh tidak hanya berurusan dengan adopsi satu inovasi melainkan seluruh prosesnya. Penyuluh adalah kunci dari keberhasilan program pemerintah dilapangan dalam rangka pembangunan bidang pertanian, peran penyuluh di lapangan sangat penting guna mentransfer informasi serta inovasi baru kepada petani (Putra et al., 2012).Keberhasilan suatu ke- 


\section{Aprilia, Lestari, Utami, Adopsi Inovasi; Peran Penyuluh,נ,}

giatan penyuluhan tersebut tidak kan persepsi petani terhadap peran terlepas dari peran Penyuluh Pertapenyuluh pertanian lapang: nian Lapang (PPL). Berikut merupa-

Tabel 1. Distribusi Responden Berdasarkan Persepsi Petani terhadap Adopsi Inovasi Rice Transplanter

\begin{tabular}{|c|c|c|c|c|c|}
\hline No & Uraian & Kategori & Skor & \multicolumn{2}{|c|}{ Distribusi } \\
\hline \multirow[t]{2}{*}{1.} & Edukator & Rendah & $8-13$ & 2 & 3,3 \\
\hline & & Tinggi & $20-24$ & 15 & 25,0 \\
\hline 2. & Motivator & Rendah & $7-11$ & 5 & 8,3 \\
\hline \multirow[t]{3}{*}{3.} & Diseminator & Rendah & $6-9$ & 3 & 5,0 \\
\hline & & Sedang & $10-13$ & 27 & 45,0 \\
\hline & & Tinggi & $14-18$ & 30 & 50,0 \\
\hline \multirow[t]{2}{*}{4.} & Supervisor & Rendah & $5-7$ & 9 & 15,0 \\
\hline & & Sedang & $8-10$ & 30 & 50,0 \\
\hline 5. & & Tinggi & $10-12$ & 10 & 16,7 \\
\hline
\end{tabular}

Sumber: Analisis Data Primer 2017

Berdasarkan tabel 1 dapat diketahui bahwa sebagian besar petani responden berpersepsi peran PPL sebagai edukator dalam kategori sedang yaitu 43 orang atau sebanyak $71,7 \%$. Sedangkan persepsi petani responden terhadap peran penyuluh dalam edukator pada tingkatan rendah hanya terdapat 2 orang dan yang untuk persepsi petani terhadap peran penyuluh dalam tingkatan tinggi terdapat 15 orang atau sebanyak $25 \%$. Kegiatan penyuluhan pertanian di Kecamatan Kebakkramat dilakukan kurang lebih sebanyak tiga kali selama satu musim tanam. Namun untuk pertemuannya sendiri PPL tidak hanya melakukan pertemuan secara formal atau sudah terjadwal saja tetapi PPL juga melakukan pertemuan di luar ruang seperti menghampiri petani yang sedang berada di lahannya. PPL aktif menyampaikan ide dan gagasan tetantang pembaruan informasi. Gagasan atau ide yang diberikan oleh PPL tidak selalu disetujui oleh petani karena terkadang tidak selalu sesuai dengan apa yang dibutuhkan petani.

\section{Persepsi Petani terhadap Peran PPL sebagai Motivator}

Berdasarkan tabel 1 dapat diketahui bahwa sebagian besar petani atau tepatnya sebesar $53,4 \%$ petani responden memiliki persepsi tinggi untuk peran petani sebagai motivator. PPL dalam memberikan motivasi dinalai baik dan penyuluh 


\section{Jurnal Agritexts Volume 42 Nomer 2 Oktober 2018}

juga memberikan penjelasan agar petani terdorong untuk menerapkan suatu inovasi. PPL menciptakan hubungan yang akrab kepada petani sehingga motivasi yang disampaikan diterima dengan baik oleh para petani. Penyuluh juga dinilai cukup sering untuk melakukan konsultasi dan juga memberikan motivasi kepada petani. Tindakan tersebut membuat para petani responden termotivasi dan bersemangat dalam melakukan usaha tani mereka dengan menerapkan suatu inovasi baru didalamnya.

Persepsi Petani terhadap Peran PPL sebagai Diseminator

Berdasarkan tabel 1 dapat diketahui bahwa sebagian besar petani responden mngategorikan peran penyuluh sebagai diseminator dalam tingkatan tinggi yaitu sebanyak $50 \%$ atau 30 orang. Hal ini disebabkan informasi yang diberikan penyuluh dirasa sudah sesuai dengan apa yang dibutuhkan oleh petani. Media informasi yang digunakan oleh penyuluh dirasa sudah cukup membantu dan dirasa sudah efektif, sehingga petani mudah menyerap materi atau sebuah informasi yang disampaikan oleh penyuluh. PPL dinilai memiliki kemampuan yang baik dalam menyampaikan informasi yang dinilai baru seperti mesin rice transplanter kepada petani. Persepsi petani terhadap PPL cukup baik karena penyuluh dinilai sudah baik dalam penyampaian informasi dan jelas pada tujuannya, sehingga mudah dipahami dan tidak berbelitbelit pada saat penyampaian informasi. PPL menggunakan bahasa yang mudah dipahami oleh petani dan informasi diberikan sesuai dengan apa yang dibutuhkan petani sehingga membuat petani ingin menerapkan suatu inovasi yang dijelaskan pada saat penyuluhan.

Persepsi Petani terhadap Peran PPL sebagai Supervisor

Berdasarkan tabel 1 dapat diketahui bahwa sebagian besar petani berpersepsi bahwa peran penyuluh sebagi supervisor dalam tingkatan sedang yaitu sebanyak $63,3 \%$ atau 38 orang. Hal ini ditunjukkan dari keaktifan PPL dalam memantau perkembangan dari lahan yang diolah petani responden, namun untuk beberapa kasus terdapat petani yang menyatakan bahwa PPL tidak terlalu berperan sebagai supervisor atau perannya dalam tingkatan rendah. Petani yang menilai peran PPL sebagai supervisor dalam tingkatan rendah sebanyak 17 orang atau $28,4 \%$. Penyuluh melakukan pemantauan dari mulai tahapan awal hingga akhir yang dimaksudkan agar ketika petani menghadapi permasalahan pada suatu tahap maka PPL dapat secara langsung memberikan solusinya. 
Aprilia, Lestari, Utami, Adopsi Inovasi; Peran Penyuluh,,,

Persepsi Petani terhadap Peran PPL sebagai Fasilitator

Berdasarkan tabel 1 dapat diketahui bahwa peran PPL sebagai fasilitator dikategorikan dalam tingkatan sedang yaitu dengan presentase $70 \%$ atau sebanyak 42 petani responden. Metode yang digunakan PPL untuk menyampaikan materi cukup beragam sehingga dapat menarik perhatian petani. PPL juga selalu bersedia untuk menjadi pembimbing dalam penggunaan mesin rice transplanter, sehingga PPL selalu terlibat dalam setiap masalah dalam penerapan inovasi rice transplanter. PPL memfasilitasi dengan mengajak petani secara langsung untuk mengamati bagaimana cara kerja mesin rice transplanter sehingga petani dapat dengan mudah memahami materi yang disampaikan.

\section{Tingkat Adopsi Inovasi pada Petani Responden}

Suatu teknologi baru tidak akan berguna tanpa adanya adopsi. Adopsi juga diartikan sebagai proses mental dalam diri seseorang melalui pertama kali mendengar tentang suatu inovasi sampai akhirnya mengadopsi (Musyafak dan Ibrahim, 2005). Berikut adalah tingkat adopsi petani responden terhadap rice transplanter.

Tabel 2. Distribusi Tingkat Adopsi Inovasi Rice Transplanter

\begin{tabular}{llllll}
\hline \hline \multirow{2}{*}{ No. } & Uraian & \multirow{2}{*}{ Kategori } & Skor & \multicolumn{2}{l}{ Distribusi } \\
\cline { 5 - 6 } & & & Orang & $\%$ \\
\hline 1. & Tingkat adopsi rice transplanter & Rendah & $18-29$ & 0 & 0,0 \\
& & Sedang & $30-41$ & 36 & 60,0 \\
& & Tinggi & $42-54$ & 24 & 40,0 \\
\hline 2. & Tingkat adopsi pada tahap pengolahan & Rendah & $3-4$ & 7 & 11,7 \\
& lahan & Sedang & $5-6$ & 31 & 51,6 \\
& & Tinggi & $7-9$ & 22 & 36,7 \\
\hline 3. & Tingkat adopsi pada tahap persiapan benih & Rendah & $7-11$ & 1 & 1,7 \\
& dan penyemaian & Sedang & $12-16$ & 23 & 38,3 \\
& & Tinggi & $17-21$ & 36 & 60,0 \\
\hline 4. & Tingkat adopsi pada tahap aplikasi rice & Rendah & $8-13$ & 4 & 6,7 \\
& transplanter & Sedang & $14-19$ & 44 & 73,3 \\
& & Tinggi & $20-24$ & 12 & 20,0 \\
\hline \hline
\end{tabular}

Sumber: Analisis data Primer 201

Tingkat Adopsi Inovasi Rice Transplanter

Berdasarkan tabel 2 dapat diketahui bahwa tingkat adopsi petani responden terhadap inovasi rice transplanter dikategorikan dalam tingkatan sedang yaitu dengan presentase $60,0 \%$ atau sebanyak 36 petani responden. Thus adoption depends on users' judgement of the value of the technology to them. Users' judgement depends on many factors some personal, others reflecting on utility and efficiency of 


\section{Jurnal Agritexts Volume 42 Nomer 2 Oktober 2018}

the technology. Adoption or rejection of technologies by users may reflect rational decision characteristics of the technologies under investigation (Sinja, 2004). Adopsi bergantung pada penilaian pengguna tentang nilai teknologi terhadap pengguna. Penghakiman pengguna bergantung pada banyak faktor, beberapa faktor lain, yang mencerminkan utilitas dan efisiensi teknologi. Adopsi atau penolakan teknologi oleh pengguna mungkin mencerminkan karakteristik keputusan rasional dari teknologi yang sedang diselidiki.

Hasil analisis diatas menunjukkan bahwa tingkat adopsi petani sudah cukup baik dengan tidak adanya yang menunjukkan bahwa tingkat adopsi dalam kategori rendah atau buruk. Hal ini menjelaskan bahwa petani sudah dapat memproses informasi yang didapatkan dan sudah dapat mengaplikasikan dalam usaha tani yang dimilikinya. Alsintan sudah banyak digunakan dalam usahatani, namun ketersediaannya masih terbatas. Secara sosial, seperti dituturkan para petani alsintan sudah diterima masyarakat antara lain karena ketersediaan tenaga kerja sudah kurang. Rice transplanter sendiri menurut para petani menjadi sangat membantu ketika tenaga kerja tani mulai berkurang.
Tingkat adopsi pada tahap Pengolahan Lahan

Berdasarkan tabel 2 dapat diketahui bahwa tingkat adopsi petani pada tahap pengolahan lahan responden terhadap inovasi rice transplanter dikategorikan dalam tingkatan sedang yaitu dengan presentase $51,6 \%$ atau sebanyak 31 petani responden. Hal ini disebabkan oleh salah satu permasalahan yaitu pemikiran petani bahwa suatu alat sudah dapat di aplikasikan maka hal lainnya tidak diperhatikan, dimana seharusnya ketinggian lapisan keras adalah pada kedalaman $40 \mathrm{~cm}$ namun pada beberapa kasus petani mengabaikannya atau kondisi lahan tidak memungkinkan untuk mendapatkan kedalaman lapisan keras sedalam 40 $\mathrm{cm}$.

Tingkat adopsi pada tahap Persiapan Benih dan Penyemaian

Berdasarkan tabel 2 dapat diketahui bahwa tingkat adopsi petani pada tahap persiapan benih dan penyemaian responden terhadap inovasi rice transplanter dikategorikan dalam tingkatan tinggi yaitu dengan presentase $60 \%$ atau sebanyak 36 petani responden. Hal ini mengartikan bahwa petani menerapkan dengan baik persipan benih dan penyemaiannya. Petani menyadari tentang pentingnya persiapan benih dan penyemaian 
dengan baik, karena nantinya akan memberi efek pertumbuhan tanaman yang cepat dan merata.

Tingkat adopsi pada tahap Aplikasi Rice Transplanter

Berdasarkan tabel 2 dapat diketahui bahwa tingkat adopsi petani pada tahap pengaplikasian rice transplanter responden dikategorikan dalam tingkatan sedang yaitu dengan presentase $73,3 \%$ atau sebanyak 44 petani responden. Hal ini mengartikan bahwa tingkat adopsi pada tahap aplikasi rice transplanter di Kecamatan Kebakkramat yaitu pada Desa Nangsri, Pulosari, dan juga Desa Waru berlangsung dengan baik, petani memahami bagaimana cara mengaplikasikannya. Hal ini ditunjukkan pula pada pemaparan penyuluh BPP
Karanganyar, bahwa petani antusisas pada awal pengenalan rice transplanter tersebut.

Hubungan antara Persepsi Petani terhadap Peran Penyuluh Pertanian Lapang (PPL) dengan Tingkat Adopsi Inovasi Rice Transplanter di Kecamatan Kebakkramat

Penelitian ini ditujukan untuk mengetahui hubungan antara persepsi petani terhadap peran Penyuluh Pertanian lapangan (PPL) dengan tingkat adopsi inovasi rice transplanter di Kecamatan Kebakkramat, seberapa besar penyuluh dapat mempengaruhi petani untuk mengadopsi suatu inovasi. Berikut adalah hasil analisis hubungan antara persepsi petani terhadap peran penyuluh dengan tingkat adopsi inovasi rice transplanter:

Tabel 3. Hubungan antara Persepsi Petani terhadap Peran PPL dengan Tingkat Adopsi Inovasi Rice Transplanter

\begin{tabular}{|c|c|c|c|c|c|c|c|c|}
\hline \multirow[t]{2}{*}{$\begin{array}{c}\text { Persepsi petani } \\
\text { terhadap peran PPL }\end{array}$} & \multicolumn{2}{|c|}{$\begin{array}{c}\text { Tingkat adopsi inovasi } \\
\text { pada tahap Pengolahan } \\
\text { Lahan (Y1) }\end{array}$} & \multicolumn{2}{|c|}{$\begin{array}{c}\text { Tingkat adopsi inovasi } \\
\text { pada tahap } \\
\text { pembenihan dan } \\
\text { penyemaian (Y2) }\end{array}$} & \multicolumn{2}{|c|}{$\begin{array}{l}\text { Tingkat adopsi inovasi } \\
\text { pada tahap aplikasi } \\
\text { Rice Transplanter (Y3) }\end{array}$} & \multicolumn{2}{|c|}{$\begin{array}{c}\text { Tingkat Adopsi Inovasi } \\
\text { Rice Transplanter } \\
\text { (Ytotal) }\end{array}$} \\
\hline & $r_{s}$ & $t_{\text {hitung }}$ & $r_{s}$ & $t_{\text {hitung }}$ & $r_{s}$ & $t_{\text {hitung }}$ & $r_{s}$ & $t_{\text {hitung }}$ \\
\hline Edukator(X1) & 0,107 & 0,820 & 0,042 & 0,320 & $0,296^{*}$ & 2,360 & 0,193 & 1.498 \\
\hline Motivator(X2) & $0,403 * *$ & 3,354 & 0,085 & 0,650 & 0,206 & 1,603 & $0,261^{*}$ & 2,059 \\
\hline Diseminator(X3) & $0,313^{*}$ & 2,510 & 0,217 & 1,693 & $0,330 * *$ & 2,662 & $0,349 * *$ & 2,836 \\
\hline Supervisor(X4) & 0,147 & 1,132 & 0,105 & 0,804 & 0,201 & 1,563 & 0,203 & 1,579 \\
\hline Fasilitator(X5) & $-0,108$ & $-0,827$ & $-0,150$ & $-1,155$ & $-0,071$ & $-0,542$ & $-0,147$ & $-1,132$ \\
\hline
\end{tabular}

Sumber: Analisis Data Primer 2017

Hubungan antaraperan penyuluh sebagai Edukator dengan Tingkat Adopsi Inovasi Rice Transplanter di Kecamatan Kebakkramat

Berdasarkan tabel 3 dapat diketahui bahwa $r_{s}$ sebesar 0,193 pada $\alpha=0,05$ dengan $t_{\text {hitung }}$ sebesar 1,498 dan $t_{\text {tabel }}$ sebesar 2,002 sehingga dapat disimpulkan bahwa $t_{\text {hitung }}<\mathrm{t}_{\text {tabel }}$ maka $\mathrm{H}_{0}$ diterima dan $\mathrm{H}_{1}$ ditolak, yang artinya tidak ada hubungan yang signifikan antara 


\section{Jurnal Agritexts Volume 42 Nomer 2 Oktober 2018}

persepsi petani terhadap peran petani sebagai edukator dengan tingkat adopsi inovasi rice transplanter di Kecamatan Kebakkramat. Penyuluh sebagai edukator menurut Mardikanto (2009) yaitu dimana kegiatan penyuluh melakukan kegiatan penyebarluasan informasi dan penjelasan yang diberikan tersebut dapat memberi efek pada petani yaitu rangsangan untuk terjadinya proses perubahan perilaku.

Hasil analisis yang menunjukkan tidak ada hubungan yang signifikan antara peran penyuluh sebagai edukator dengan tingkat adopsi yang bertentangan dengan pernyataan Mardikanto (2009) yang disebutkan diatas bahwa dengan peran penyuluh sebagai edukator dapat merubah perilaku petani. Hal ini dikarenakan petani tidak dapat dipaksa oleh petugas pertanian agar mau menerima dan menerapkan segala sesuatunya. Petani berhak memutuskan sendiri segala sesuatu yang diterimanya, berdasarkan pertimbangannya. Maka penyuluh dalam melaksanakan tugas harus dapat bekerjasama dengan petani dalam kegiatan usaha taninya

Hubungan antara Persepsi Petani terhadap Peran Penyuluh sebagai Motivator dengan Tingkat Adopsi Inovasi Rice Transplanter di Kecamatan Kebakkramat

Berdasarkan tabel 3 diatas dapat diketahui bahwa $r_{s}$ sebesar
$0,261^{*}$ pada $\alpha=0,05$ dengan $t_{\text {hitung }}$ sebesar 2,059 dan $t_{\text {tabel }}$ sebesar 2,002 sehingga dapat disimpulkan bahwa $t_{\text {hitung }}>t_{\text {tabel }}$ pada taraf signifikansi $95 \%$ maka $\mathrm{H}_{0}$ ditolak dan $\mathrm{H}_{1}$ diterima, yang artinya terdapat hubungan yang signifikan antara persepsi petani terhadap peran penyuluh sebagai motivator dengan tingkat adopsi inovasi rice transplanter di Kecamatan Kebakkramat. Hubungan yang signifikan antara peran penyuluh sebagai motivator dengan tingkat adopsi inovasi menunjukkan bahwa penyuluh berhasil dalam perannya sebagai motivator sehingga dapat mempengaruhi petani untuk mengadopsi inovasi rice transpanter.

Hasil penelitian ini sesuai dengan pernyataan Nasution (1990) yaitu peran penyuluh sebagai motivator akan menimbulkan keinginan dan membuat petani tergerak untuk mengadopsi inovasi. Penyuluh berperan baik dalam mendorong petani untuk menerima teknologi yang baru, menumbuhkan kesadaran dan menggerakkan partisipasi petani, dan melaksanakan perubahan yang direncanakan. Motivasi terhadap petani tidak terbatas pemberiannya pada saat kegiatan penyuluhan saja, para penyuluh juga melakukan kunjungan terhadap lahan pertanian para petani tersebut. Hal ini membuat petani merasa lebih diperhatikan sehingga dalam pene- 
rapan suatu teknologi yang disampaikan oleh penyuluh dapat berlangsung dengan baik.

Hubungan antara Persepsi Petani terhadap Peran Penyuluh sebagai Diseminator dengan Tingkat Adopsi Inovasi Rice Transplanter di Kecamatan Kebakkramat

Berdasarkan tabel 3 dapat diketahui bahwa $r_{s}$ sebesar 0,349** pada $\alpha=0,05$ dengan $t_{\text {hitung }}$ sebesar 2,836 dan $t_{\text {tabel }}$ sebesar 2,002 sehingga dapat disimpulkan bahwa $t_{\text {hitung }}>t_{\text {tabel }}$ pada taraf signifikansi 99\% maka $\mathrm{H}_{0}$ ditolak dan $\mathrm{H}_{1}$ diterima, yang artinya terdapat hubungan yang sangat signifikan antara persepsi petani terhadap peran penyuluh sebagai diseminator dengan tingkat adopsi inovasi rice transplanter di Kecamatan Kebakkramat. Sumber informasi menurut Soekartawi (1988) sangatlah berpengaruh terhadap proses adopsi inovasi, dimana saat satu sumber informasi itu adalah penyuluh pertanian lapangan. Hubungan yang sangat signifikan antara peran penyuluh sebagai diseminator dengan tingkat adopsi inovasi menunjukkan bahwa penyuluh berhasil dalam perannya sebagai diseminator sehingga dapat mempengaruhi petani untuk mengadopsi inovasi rice transpanter.

Hasil penelitian ini sesuai denganpernyataan Samsudin (1976) yang mengatakan bahwa fungsi atau peran penyuluh pertanian adalah sebagai penghubung yang menjabarkan proses penyampaian ilmu dan teknologi pertanian, dari sumbernya kepada masyarakat tani yang membutuhkannya sehingga proses adopsi inovasi berjalan dengan baik. Setiana (2005) menjelaskan bahwa fungsi penyuluhan adalah menjembatani kesenjangan antara praktik yang biasa dijalankan oleh para petani dengan pengetahuan dan teknologi yang selalu berkembang. dengan demikian, penyuluhan dengan penyuluhnya merupakan penghubung yang bersifat dua arah (two way traffic) dan penyuluh mampu menjadi jembatan penghubung antara pemerintah dan masyarakat sehingga peran penyuluh sebagai diseminator berpengaruh positif pada tingkat adopsi inovasi petani.

Hubungan antara Persepsi Petani terhadap Peran Penyuluh sebagai Supervisor dengan Tingkat Adopsi Inovasi Rice Transplanter di Kecamatan Kebakkramat

Berdasarkan tabel 3 dapat diketahui bahwa $r_{s}$ sebesar 0,203 pada $\alpha=0,05$ dengan thitung sebesar 1,579 dan $t_{\text {tabel }}$ sebesar 2,002 sehingga dapat disimpulkan bahwa $t_{\text {hitung }}<\mathrm{t}_{\text {tabel }}$ maka $\mathrm{H}_{0}$ diterima dan $\mathrm{H}_{1}$ ditolak, yang artinya tidak ada hubungan yang signifikan antara persepsi petani terhadap peran penyuluh sebagai supervisor dengan tingkat adopsi inovasi rice trans- 


\section{Jurnal Agritexts Volume 42 Nomer 2 Oktober 2018}

planter di Kecamatan Kebakkramat. Penyuluh sebagai Supervisor yaitu para penyuluh melakukan pengawasan dalam kegiatan pertanian, namun menurut Mardikanto (2009) supervisi ini merupakan upaya bersama klien melakukan penilaian yang kemudian memberikan saran alternatif.

Hasil penelitian ini tidak sesuai dengan apa yang dijelaskan oleh Mardikanto (2009) tersebut, dimana petani menilai penyuluh tidak mengetahui kelemahan yang ditemui selama kegiatan penyuluhan di lapangan sehingga tidak dapat disusun bimbingan yang tepat kepada pelaksana petani agar kelemahan dan kekurangan dapat dikurangi sekecil mungkin. Suhardiyono (1992) menjelaskan tujuan dilakukannya supervisi terhadap kegiatan penyuluhan adalah untuk mengetahui apakah program penyuluhan yang telah disusun dapat berjalan sesuai dengan yang diharapkan atau tidak, disamping itu juga diperlukan untuk mengetahui apakah terdapat kekurangan atau kelemahan di dalam pelaksanaan kegiatan penyuluhan di lapangan. Hal ini sangat penting untuk mempermudah petani dalam menerapkan suatu teknologi, namun pada pelaksanannya persepsi petani untuk mengadopsi tidak dipengaruhi oleh peran penyuluh sebagai supervisor.
Hubungan antara Persepsi Petani terhadap Peran Penyuluh sebagai Fasilitator dengan Tingkat Adopsi Inovasi Rice Transplanter di Kecamatan Kebakkramat

Berdasarkan tabel 3 dapat diketahui bahwa $r_{s}$ sebesar $-0,147$ pada $\alpha=0,05$ dengan thitung sebesar 1,132 dan $t_{\text {tabel }}$ sebesar 2,002 sehingga dapat disimpulkan bahwa $t_{\text {hitung }}<\mathrm{t}_{\text {tabel }}$ maka $\mathrm{H}_{0}$ diterima dan $\mathrm{H}_{1}$ ditolak, yang artinya tidak ada hubungan yang signifikan antara persepsi petani terhadap peran penyuluh sebagai supervisor dengan tingkat adopsi inovasi rice transplanter di Kecamatan Kebakkramat. Hal ini bahwa peran penyuluh sebagai fasilitator tidak dapat mempengaruhi persepsi petani untuk mengadopsi.

Mardikanto (2009) menyatakan bahwa penyuluh pertanian diarahkan untuk melaksanakan tugas pendampingan dan konsultasi bagi pelaku utama dan pelaku usaha dalam mengembangkan usaha agribisnisnya, sehingga adopsi teknologi tepat guna dapat berjalan dengan baik dan pada gilirannya meningkatkan pemberdayaan pelaku utama, produksi, produktivitas, pendapatan dan kesejahteraan petani beserta keluarganya. Namun hasil dari penelitian ini tidak sesuai dengan peran penyuluh sebagai fasilitator atau pendampingan yang lebih 


\section{Aprilia, Lestari, Utami, Adopsi Inovasi; Peran Penyuluh,נ,}

bersifat melayani kebutuhan yang dirasakan client-nya. Fungsi fasilitator yang tidak selalu mengambil keputusan, memecahkan masalah, tetap saja tidak dapat mempengaruhi petani untuk mengadopsi inovasi rice transplanter. Petani tidak merasa penyuluh berperan penting dan selalu memfasilitasi untuk mendukung kegiatan mereka, beberapa petani mengeluhkan penyuluh kurang berperan aktif dan tidak selalu terlibat dalam kegiatan.

\section{KESIMPULAN DAN SARAN}

\section{Kesimpulan}

Berdasarkan hasil penelitian dan pembahasan, maka kesimpulan dari penelitian ini adalah:Persepsi petani responden terhadap peran penyuluh di Kecamatan Kebakkramat adalah sebagai berikut:Persepsi petani terhadap peran penyuluh sebagai edukator dapat dikatakan cukup baik; persepsi petani terhadap peran penyuluh sebagai motivator dapat dikatakan baik; persepsi petani terhadap peran penyuluh sebagai diseminator dapat dikatakan baik; persepsi petani terhadap peran penyuluh sebagai supervisor dapat dikatakan cukup baik; persepsi petani terhadap peran penyuluh sebagai fasilitator dapat dikatakan baik.

Tingkat adopsi mesin rice transplanter pada petani di Kecamatan Kebakkramat yaitu: tingkat adopsi inovasi pada keseluruhan tahap dapat dikatakan cukup baik; tingkat adopsi inovasi pada tahap pengolahan lahan dapat dikatakan cukup baik; tingkat adopsi inovasi pada tahap persiapan benih dan penyemaian dapat dikatakan baik; tingkat adopsi inovasi pada tahap aplikasi rice transplanter dapat dikatan cukup baik.

Hubungan antara persepsi petani terhadap peran penyuluh dengan tingkat adopsi inovasi rice transplanter adalah sebagi berikut: terdapat hubungan yang tidak signifikan antara persepsi petani terhadap peran penyuluh sebagai edukator dengan tingkat adopsi inovasi rice transplanter; terdapat hubungan yang signifikanpada taraf kepercayaan $95 \%$ antara persepsi petani sebagai motivator terhadap peran penyuluh dengan tingkat adopsi inovasi rice transplanter; terdapat hubungan yang signifikan pada taraf kepercayaan $99 \%$ antara persepsi petani terhadap peran penyuluh sebagai diseminator dengan tingkat adopsi inovasi rice transplanter; terdapat hubungan yang tidak signifikan antara persepsi petani terhadap peran penyuluh sebagai supervisor dengan tingkat adopsi inovasi rice transplanter; terdapat hubungan yang tidak signifikan antara persepsi petani terhadap peran penyuluh sebagai fasilitator 


\section{Jurnal Agritexts Volume 42 Nomer 2 Oktober 2018}

dengan tingkat adopsi inovasi rice transplanter.

\section{Saran}

Berdasarkan kesimpulan hasil penelitian ini, maka saran yang dapat diajukan adalah sebaiknya penyuluh dapat berperan lebih baik lagi dalam hal menyebarkan informasi atau inovasi kepada petani sehingga akan menimbulkan persepsi yang positif bagi petani, karena sesuatu yang baru tidak dapat secara langsung diterima oleh petani dan harus lebih jelas dalam menjelaskan kegunaannya dan apa keuntungannya jika menerapkan suatu teknologi baru tersebut sehingga proses adopsi inovasi berjalan dengan baik. Peran sebagai motivator dapat ditingkatkan dengan mengadakan konsultasi dengan petani sehingga penyuluh dapat mengetahui permasalahan yang sedang dihadapi oleh petani dan penyuluh dapat memberikan motivasi kepada petani dan juga saran agar permasalahan dapat diatasi. Kemudian untuk peran penyuluh sebagai diseminator, penyuluh dapat melakukan pembaruan informasi dengan frekuensi yang tepat. Hal ini ditujukan agar informasi dapat diserap dan diterima oleh petani secara baik, dan petani juga dapat selalu update dengan pembaharuan yang ada.

Inovasi yang diberikan pada petani sebaiknya tidak hanya dilihat dari permasalahan yang dihadapi oleh petaninamun dilihat juga pada kondisi lahan yang diolah oleh petani apakah sesuai dengan inovasi tersebut atau tidak. Inovasi yang sesuai dengan permasalahan maka petani akan dapat lebih terbuka dalam menerima inovasi dari penyuluh pertanian yang ditujukan untuk membantu petani itu sendiri dalam usaha taninya. Keterbukaan petani akan inovasi dapat mempermudah proses adopsi inovasi sehingga apa yang menjadi tujuan dari adanya inovasi tersebut dapat terlaksana dengan baik.

\section{DAFTAR PUSTAKA}

Adesina, A., Zinnah, M., 1993. Technology characteristics, farmers' perception and adoption decision: a tobit model application in Sierra Leone. Journal Agricultural Economics Vol. 9.

Badan Pusat Statistik Kabupaten Karanganyar. 2016. Karanganyar dalam Angka 2016. Badan Pusat Statistik Kabupaten Karanganyar. Karanganyar.

Ban dan Hawkins. 2003. Penyuluhan Pertanian. Yogyakarta: Kanisius.

Hadiutomo, K. 2012. Mekanisasi Pertanian. Bogor: IPB Press.

Mardikanto, T dan Sutarni, S. 1982. Pengantar Penyuluhan Pertanian. Surakarta: Haspara. 
Aprilia, Lestari, Utami, Adopsi Inovasi; Peran Penyuluh,,,

Mardikanto, T. 2009. Sistem penyuluhan Pertanian. Surakarta: LPP UNS dan UNS Press.

Mulyana, D. 2001. IImu Komunikasi, Suatu Pengantar. Bandung: Remaja Rosdakarya.

Musyafak, Ahmad dan Tatang M. Ibrahim. 2005. Strategi Percepatan Adopsi dan Difusi Inovasi Pertanian mendukung Prima Tani. Jurnal ANALISIS KEBIJAKAN PERTANIAN Vol.3(1).

Nasution. 1990. Prinsip-Prinsip Komunikasi untuk Penyuluhan. Jakarta: LPFE-UI.

Putra, Hariyadi, dan Harsoyo. 2012. Pengaruh Peran Penyuluh Dan Kearifan Lokal Terhadap Adopsi Inovasi Padi Sawah Di Kecamatan Montasik Kabupaten Aceh Besar. Jurnal KANAL Vol.1(1).

Robert and Timothy. Factors Influencing the Adoption of a Nitrogen Testing Program. JOURNAL of Extension Vol 33 (4).

Sairi, A. 2015. Peran Petugas Penyuluh Pertanian Dalam Mengembangkan Budidaya Padi Di Desa
Sumber Sari Kecamatan Loa Kulu Kabupaten Kutai Kartanegara. eJunal ILMU KOMUNIKASI Vol.3(2).

Samsudin, U. 1976. Dasar - Dasar Penyuluhan dan Modernisasi Pertanian. Bandung: Binacipta.

Setiana, L. 2005. Teknik Penyuluhan dan Pemberdayaan Masyarakat. Bogor: Graha Indonesia.

Singarimbun dan Efendi. 1986. Metode penelitian Survey. Jakarta: Media Pratama.

Sinja, Judith. 2004. 2004. African Association of Agricultural Economists. http://ageconsearch. umn. edu. Diakses pada 6 Agustus 2017.

Soekartawi. 1988. Prinsip Dasar: Komunikasi Pertanian. Jakarta: UI Press.

Sugiyono. 2015. Metode Penelitian kuantitatif, Kualitatif, dan R\&D. Bandung: Alfabeta.

Sugiyono. 2015. Statistik Nonparametris untuk Penelitian. Bandung: Alfabeta.

Suhardiyono, L. 1992. Penyuluhan: Petunjuk bagi Penyuluh Pertanian. Jakarta: Erlangga. 